\title{
Breaking internal waves on a Florida (USA) coral reef: a plankton pump at work?
}

\author{
James J. Leichter ${ }^{1, *}$, Gregory Shellenbarger ${ }^{2}$, Salvatore J. Genovese ${ }^{3}$, \\ Stephen R. Wing ${ }^{4}$
}

\author{
${ }^{1}$ Woods Hole Oceanographic Institution, Department of Biology, MS \#34, Woods Hole, Massachusetts 02543, USA \\ ${ }^{2} 1$ Lincoln Street, Marblehead, Massachusetts 01945, USA \\ ${ }^{3}$ Northeastern University, Marine Science Center, Nahant, Massachusetts 01908, USA \\ ${ }^{4}$ Department of Marine Science, University of Otago, 304 Castle Street, Dunedin, New Zealand
}

\begin{abstract}
Temperature, salinity, flow speeds, and planklon concentrations can be highly variable on the slope of Conch Reef, Florida Keys (USA), as warm surface water is mixed with cool, subsurface water forced onshore by broken internal waves. In August 1995 the water column seaward of the reef exhibited strong temperature and density stratification with a sharp pycnocline and associated subsurface chlorophyll a maximum layer at 45 to $60 \mathrm{~m}$ depth. On the reef slope, near-bottom zooplankton sampling at 22 to $28 \mathrm{~m}$ showed high concentrations of calanoid copepods, crab zoea, and fish larvae associated with upslope flow of cool, chlorophyll-rich water. In contrast to these periods of high concentrations, zooplankton concentrations were low during periods of long-shore and offshore flow of warm surface waters. Both the frequency of internal bore arrival and the mean duration of cool water events increase with increasing depth on the reef slope. Delivery of zooplankton to the reef is, therefort, âlso expected to incrcasc with dopth. A short-term settlement experiment showed increased settlement of serpulid worms at 20 and $30 \mathrm{~m}$ depth compared with $15 \mathrm{~m}$, and a 15.5 mo transplant experiment showed significantly enhanced growth rates of the suspension-feeding coral Madracis mirabilis (Scleractinia: Pocilloporidae) at $30 \mathrm{~m}$ depth relative to growth at 15 or $20 \mathrm{~m}$. Internal tidal bores appear to be a predictable, periodic source of cross-shelf transport to Florida coral reefs and an important influence on the spatial and temporal heterogeneity of suspended food particles and larval delivery to the benthos.
\end{abstract}

KEY WORDS: Internal waves - Internal bores - Zooplankton · Transport

\section{INTRODUCTION}

Most marine invertebrates and fish produce some form of dispersing, planktonic larvae (Thornson 1950, Young 1990, Farrell et al. 1991, Gaines \& Bertness 1992, Shanks 1995) and the population dynamics of these marine organisms can be strongly influenced by the wide range of biological and physical processes that determine the fate of larvae (e.g. Gaines \& Roughgarden 1985, Roughgarden et al. 1987, Possingham \& Roughgarden 1990, Bertness et al. 1996, Underwood \& Chapman 1996). Understanding the details of these influences is often hindered by the virtual impossibility of tracking cohorts of microscopic larvae over vast dis-

•E-mail: jleichter@whoi.edu persal distances and long durations of planktonic phases. However, significant advances in understanding larval recruitment processes have been made where physical transport mechanisms have been determined. For example, relaxation of upwelling along central California, USA, produces periods of onshore, cross-shelf transport and coastal buoyancy currents that have been linked to recruitment pulses in intertidal barnacles (Gaines \& Roughgarden 1985, Farrell et al. 1991) and coastal crabs (Wing et al. 1995a, b). Focus on the complexities of tidal flows in estuaries and the recognition that currents at different depths can move in different directions, combined with studies of the behavioral aspects of larval depth regulation, has led to greater understanding of dispersal and recruitment of brachyuran crabs (Sulkin 1984, see Epifanio 1995). Studies of surface oceanographic features 
such as eddies, jets, and fronts in the vicinity of coral reefs have advanced the understanding of local and long range dispersal of coral reef invertebrates and fish (e.g Cowen \& Castro 1994, Schultz \& Cowen 1994, see Sammarco \& Heron 1994).

Cross-shelf transport-the exchange of water between coastal and oftshore environments - strongly influences dispersal of meroplanktonic larvae and can connect adult subpopulations along large stretches of coastline through shared offshore larval pools (Botsford et al. 1994). Internal tidal bores generated by breaking internal waves have recently been identified as one mechanism of cross-shelf transport of cool, subsurface water in several habitats (Pineda 1991, 1994, Shanks 1995), including the slopes of coral reefs in the Florida Keys, USA (Leichter et al. 1996). Evidence of internal tidal bores includes rapid, step-like changes in temperature and salinity, abrupt onset of up-slope flows near the bottom often coupled with offshore near-surface flows, and packets of high frequency internal waves following the fronts of bores (Shanks 1995). During periods of stable water column density stratification seaward of the Florida Keys, internal tidal oscillations generate packets of internal waves traveling shoreward along the thermocline at depths of 50 to $80 \mathrm{~m}$ (Leichter et al. 1996). Upon running into shallow water, these internal waves can break into turbulent, cool-water internal bores up to $10 \mathrm{~m}$ in height that continue traveling inshore and up the reef slope at speeds of 0.1 to $0.3 \mathrm{~m} \mathrm{~s}^{-1}$. While ambient surface waters are typically characterized by low concentrations of dissolved nutrients and suspended particles, the water transported in internal bores can contain much higher concentrations of inorganic nutrients and phytoplankton. The arrival of cool-water bores is linked to semidiurnal tidal frequencies and can be modulated by lunar frequencies and seasonal variability. Typical residence times for cool water on the reef slope range from one to several hours, with both the frequency and duration of cool-water events increasing with depth on the reef slope (Leichter et al. 1996, Leichter 1997).

The arrival of internal bores on the reef slope may affect the supplies of food particles to suspension feeders, dissolved nutrients to corals and benthic algae, and planktonic larvae to the benthos. Internal waves and internal bores appear to be a consistent, predictable source of cross-shelf transport of cool, subsurface water in many nearshore habitats (Shanks 1995) and have long been recognized as a potential source of transient upwelling in coastal marine environments (e.g. Cooper 1947, Wolanski \& Pickard 1983, Sandstrom \& Elliot 1984). Unbroken internal waves have been linked to high frequency downward delivery of warm, phytoplankton-rich water to benthic suspension-feeding communities on rocky subtidal habitats in the Gulf of Maine, USA (Witman et al. 1993). It is likely that meroplanktonic larvae may be transported in internal bores (Shanks 1995, Pineda 1991); however, field studies to date have only investigated this along the coast of southern California, where water column concentrations of crab and barnacle larvae appear to increase with the arrival of surface fronts associated with near-bottom internal tidal bores and secondary onshore surface flows (Pineda 1991, 1994, J. Pineda pers. comm.).

This study was an attempt to sample zooplankton quantitatively during the arrival of internal bores at Conch Reef, Florida Keys, and to examine potential differences across depths on the reef slope in 2 processes potentially influenced by plankton transport in internal bores: invertebrate settlement and growth rate of a suspension-feeding coral. Direct evidence for delivery of zooplankton to the reef slope is presented along with 2 lines of indirect evidence that suggest increased particle flux with increasing depth on the reef slope may, indeed, have important organismaland community-level consequences.

\section{METHODS}

Site description. A combination of physical and biological sampling was conducted at Conch Reef, Florida Keys $\left(24^{\circ} 59^{\prime} \mathrm{N}, 80^{\circ} 25^{\prime} \mathrm{W}\right)$, and the offshore waters of the Florida Straits in August 1995. Sites were accessed from small boats and both Nitrox $\left(36 \% \mathrm{O}_{2}\right)$ and $10 \mathrm{~d}$ of saturation SCUBA diving. Conch Reef is a Holocene fringing reef lying along the submerged Pleistocene margin of Key Largo (Shinn et al. 1989) in the upper Florida Keys (Fig. 1). Coral spur and groove formations run down the fore reef from approximately 12 to $30 \mathrm{~m}$ depth, where the formations break into isolated patches on sand. At approximately $35 \mathrm{~m}$ the reef ends on a gently sloping sand plain that extends 8 to $10 \mathrm{~km}$ to the deeper channel of the Florida Straits. The axis of the Florida Current typically runs 5 to $10 \mathrm{~km}$ offshore of the reef. Near-bottom currents on the reef are characterized by variable, tidally driven flows up to $0.25 \mathrm{~m}$ $\mathrm{s}^{-1}$ predominantly in an along-shore, $60^{\circ} / 240^{\circ}$ axis (Leichter et al. 1996, S. Miller unpubl. data). Alongshore flows can be interrupted by 0.10 to $0.30 \mathrm{~m} \mathrm{~s}^{-1}$ surges of up-slope, $330^{\circ}$ flow as cool water is forced onshore by internal tidal bores (Leichter et al. 1996). In 1995 the annual mean water temperature at $33 \mathrm{~m}$ was $25.9^{\circ} \mathrm{C}$ with an $8.8^{\circ} \mathrm{C}$ range of daily means from 20.6 to $29.4^{\circ} \mathrm{C}$ (S. Miller unpubl. data). The maximum range of temperatures within a single day at $33 \mathrm{~m}$ during 1995 was $7.5^{\circ} \mathrm{C}$. Hydrographic conditions at this site also vary seasonally and under the influence of low frequency, large scale variability associated with the 


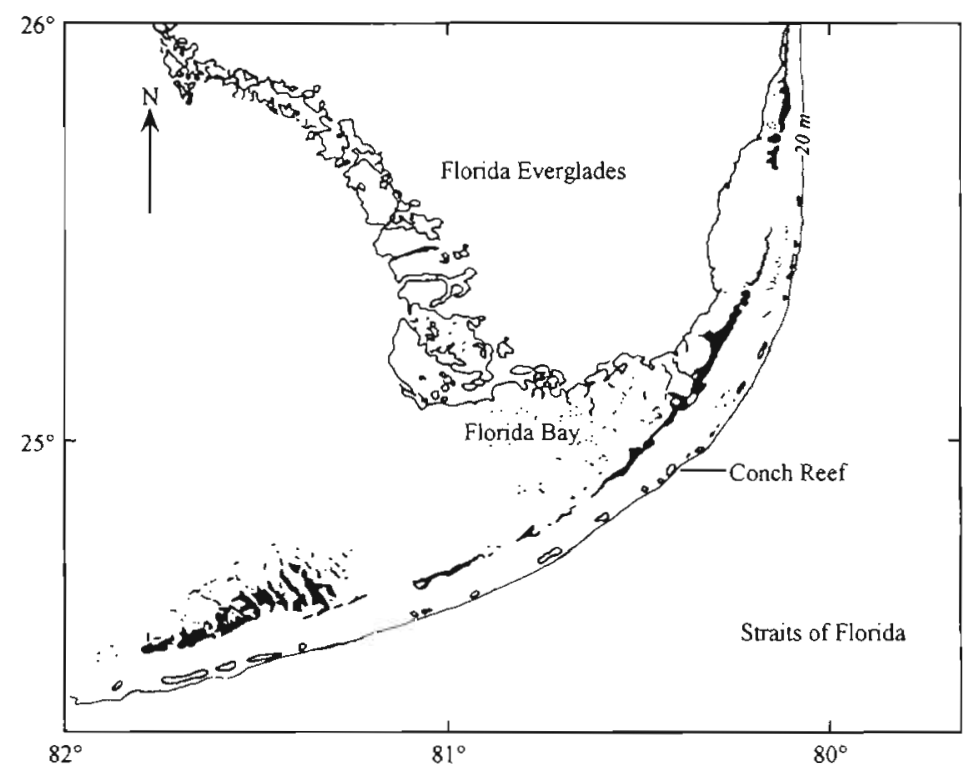

Fig. 1. Map of southern Florida, with the Florida Keys and offshore reef track including Conch Reef $\left(24^{\circ} 59^{\prime} \mathrm{N}, 80^{\circ} 25^{\prime} \mathrm{W}\right)$. The approximate location of the $20 \mathrm{~m}$ bathymetric contour seaward of the reef track is indicated

Florida Current. Surface tides along the upper Florida Keys are semi-diurnal with amplitudes of 0.2 to $0.4 \mathrm{~m}$ varying on a fortnightly semi-lunar cycle.

Physical sampling. Water column temperature, salinity and chlorophyll a concentrations were measured with a SeaBird SB-19 conductivity-temperaturedepth meter (CTD) with attached SeaTech fluorometer, factory calibrated within 2 mo prior to use. On 4 days in August 1995, CTD casts from the surface to within $2 \mathrm{~m}$ of the bottom were made at stations positioned every $1.85 \mathrm{~km}$ ( 1 nautical mile) along a line extending $11 \mathrm{~km}$ offshore (at $150^{\circ}$ ) from the reef crest. Temperature, salinity, density and chlorophyll a profiles were produced by averaging data from a single CTD cast at each station into $1 \mathrm{~m}$ depth bins. Section plots were produced by interpolation between casts with the contouring program Surfer (Golden Software, Inc.).

Movements of cool-water masses onto and off the reef were measured with an array of recording instruments similar to that described by Leichter et al. (1996) fixed on the reef slope from August 3 to 23, 1995 (21 d). Flow speed and direction along with temperature and salinity were measured with an Interocean S4 electromagnetic current meter mounted $1 \mathrm{~m}$ above the bottom at $35 \mathrm{~m}$ depth. This instrument sampled at $0.5 \mathrm{~s}$ intervals, recording $1 \mathrm{~min}$ averages for the duration of the $21 \mathrm{~d}$ deployment. Temperature and salinity through the water column above the reef were measured by rapid CTD profiling and with a vertical array of thermistors connected to a single housed data logger. Tem- perature was also measured synchronously at 8 positions across the reef front from 15 to $35 \mathrm{~m}$ with individually-housed recording temperature meters (Onset Computers Stowaway) fixed $1 \mathrm{~m}$ above the bottom, sampling at $0.5 \mathrm{~s}$ intervals and recording $1 \mathrm{~min}$ averages throughout the $21 \mathrm{~d}$ deployment. To ensure rapid response times to temperature changes ( $<20$ s response to $5^{\circ} \mathrm{C}$ change) thermistor beads were placed inside hollow stainless steel pins inserted through the pressure housings. Long-term temperature data were also collected with Ryan Tempmentors fixed $1 \mathrm{~m}$ above the bottom at 21 and $33 \mathrm{~m}$, recording at $20 \mathrm{~min}$ intervals throughout 1995 and 1996.

Biological sampling and coral growth rate experiment. Zooplankton concentrations $1 \mathrm{~m}$ above the bottom at 22 and $28 \mathrm{~m}$ depths were sampled with a $1.0 \mathrm{~m}^{2}$ plankton net of $105 \mu \mathrm{m}$ mesh propelled over the reef by swimming SCUBA divers (Fig. 2). This method had an advantage over towing nets from boats of allowing sampling very close to the bottom while providing for direct visual observations of conditions. The net was mounted on a rigid rod held in front of the divers to prevent interference by diver bubbles and wakes. Water volume sampled was estimated with a General Oceanics flow meter mounted in the mouth of the net, and the total distance covered on every 'tow' was standardized by traveling twice along a $50 \mathrm{~m}$ travel line (once on either side to avoid resampling the same water) fixed on the bottom. Each tow, therefore, covered $100 \mathrm{~m}$ total sampling distance and approximately $100 \mathrm{~m}^{3}$ standard sample volume. Tows were made parallel to depth contours (perpendicular to the reef

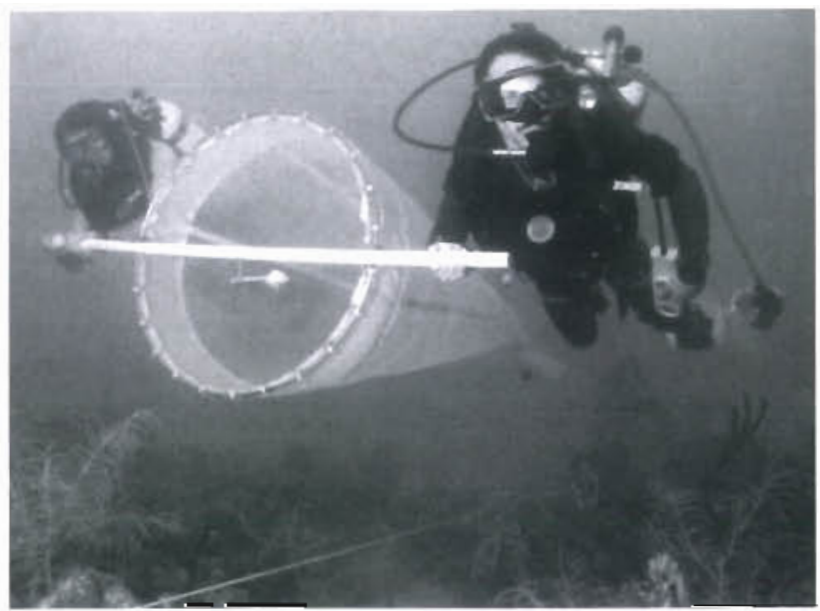

Fig. 2. A $1 \mathrm{~m}^{2}$ plankton net propelled $1 \mathrm{~m}$ above the reef by SCUBA divers 
slope). From August 15 to 20, 1995, 2 paired plankton samples were taken at 22 and $28 \mathrm{~m}$ each morning between 09:00 and 11:00 $\mathrm{h}$ and each afternoon between 15:00 and 17:00 h ( 8 samples per day). Previous data (Leichter et al. 1996) and information collected in the days immediately preceding plankton sampling indicated arrival of cool water occurred at roughly $12 \mathrm{~h}$ intervals, lasting for periods of one to several hours. By spacing plankton samples regularly throughout the day, the sampling scheme was designed to cover periods both with and without the presence of cool water on the reef slope. Plankton samples were fixed immediately after collection in $10 \%$ buffered formalin in sea water and subsequently transferred to $95 \%$ EtOH. Total volume collected in each sample was measured by displacement in a graduated cylinder of sea water at $25^{\circ} \mathrm{C}$, and the entire samples were sorted under dissecting microscopes. Zooplankton were separated into broad taxonomic groups and counted with particular attention to calanoid copepods (by far the most abundant constituents of the samples), crab zoea, fish larvae, and fish eggs. The most abundant copepod species were identified following Owre \& Foyo (1967). Crab zoeae and fish larvae were identified to family level wherever possible. Within taxonomic groups, concentrations are expressed as number of individuals divided by volume of water sampled.

A short-term invertebrate settlement experiment was conducted in August 1995 to assess possible contributions of internal bores to larval delivery patterns across the reef front. Settlement collectors consisted of $47 \mathrm{~mm}$ outside diameter by $150 \mathrm{~mm}$ long PVC pipes covered with $3 \mathrm{M} \# 7740$ anti skid tape. This tape has been used in previous settlement studies (e.g. Farrell et al. 1991) and provides a rough surface for settlement while ensuring uniform rugosity among collectors. Collectors were attached $0.5 \mathrm{~m}$ above the bottom to individual weighted lines with floats and deployed at 15, 20, and $30 \mathrm{~m}$ from August 3 to 23, 1995. Ten replicate collectors were deployed at each depth. Upon retrieval, collectors were air dried, examined under a dissecting microscope, and all settled invertebrates counted and identified to family level. Settlement data were compared statistically between depths using a non-parametric Kruskal-Wallis test. The non-parametric test was used because the small sample sizes $(10$ collectors) within depths led to apparent departures from normality of the data. Post hoc comparisons between depths were made with a non-parametric Tukey-type multiple comparison test (Zar 1984).

A longer-term manipulative experiment was conducted to examine possible effects on coral growth rates of variable internal bore impact with depth. Individual branches of the Pocilloporid finger coral Madracis mirabilis (Duchassaing and Michelotti), 25 to
$40 \mathrm{~mm}$ in length and 5 to $8 \mathrm{~mm}$ in diameter, were collected from 10 to 12 colonies at 20 to $25 \mathrm{~m}$ depth on the reef slope on August 18, 1995. Corals were kept submerged in sea water, briefly removed for measurement of wet weight, length, and number of branches, and randomly assigned to experimental treatments to randomize possible effects of colony origin. Ten coral fragments were attached to marked positions on each of 3 racks deployed to each of 3 depths, 15,20 , and $30 \mathrm{~m}$ $(10$ corals per rack $\times 3$ racks per depth $\times 3$ depths $=90$ individuals). Racks were individually anchored and deployed on the reef on August 18, 1995. One-factor analysis of variance (ANOVA), used to test for possible differences among racks in initial coral weights, indicated no significant differences $(F=1.013, \mathrm{p}=0.435$, $\mathrm{df}=8,68$ )

On December 4, 1996, $474 \mathrm{~d}$ after the start of the transplant experiment, all racks were retrieved. Wet weight and final number of branches were measured and corals were subsequently dried to a constant weight at $50^{\circ} \mathrm{C}$ (dried at least $12 \mathrm{~h}$ ) and then weighed dry. Linear regression of final dry weight to final wet weight $\left(y=0.773 x+0.244 ; r^{2}=0.990\right)$ was used to back-calculate initial dry weight. Final skeletal volumes were measured by application of Archimedes' principle: the difference between the weight $(g)$ of each coral in air and its buoyant weight in water (measured by suspending corals from a Mettler balance into fresh water at $\left.20^{\circ} \mathrm{C}\right)$ is equivalent to the volume $\left(\mathrm{cm}^{3}\right)$ multiplied by the density of fresh water (assumed to be $\left.1.0 \mathrm{~g} \mathrm{~cm}^{-3}\right)$. Regression of final wet weight to final volume $\left(y=1.58 x+0.852 ; r^{2}=0.964\right)$ was used to backcalculate initial volume from the measured initial wet weights. Fractional changes in both weight and volume were calculated as the difference between final. and initial values divided by initial value: $\Delta=$ size $_{2}-$ size $\left._{1}\right) /$ size $_{1}$. Changes in volume, weight, and number of branches were each compared statistically by analysis of covariance (ANCOVA) with the fixed factor depth, initial weight as the covariate, and transplant rack as a factor nested within depths. ANCOVAs were run in 2 steps: First, the effects of the nested treatment factor (racks), the covariate (initial weight), and the interaction between these factors were tested for significance. A non-significant interaction between racks and initial weight indicates homogeneity of slopes in the ANCOVA model. Second, if the interaction between racks and initial weight was non-significant, this term was dropped from the model and the effects of the main treatment factor (depth), the nested factor (rack) and the covariate (initial weight) were tested. Data on fractional increase of skeletal. weight and volume were arcsine-square-root transformed prior to ANCOVA to improve normality and homogeneity of variances. Branch number data were log transformed. 


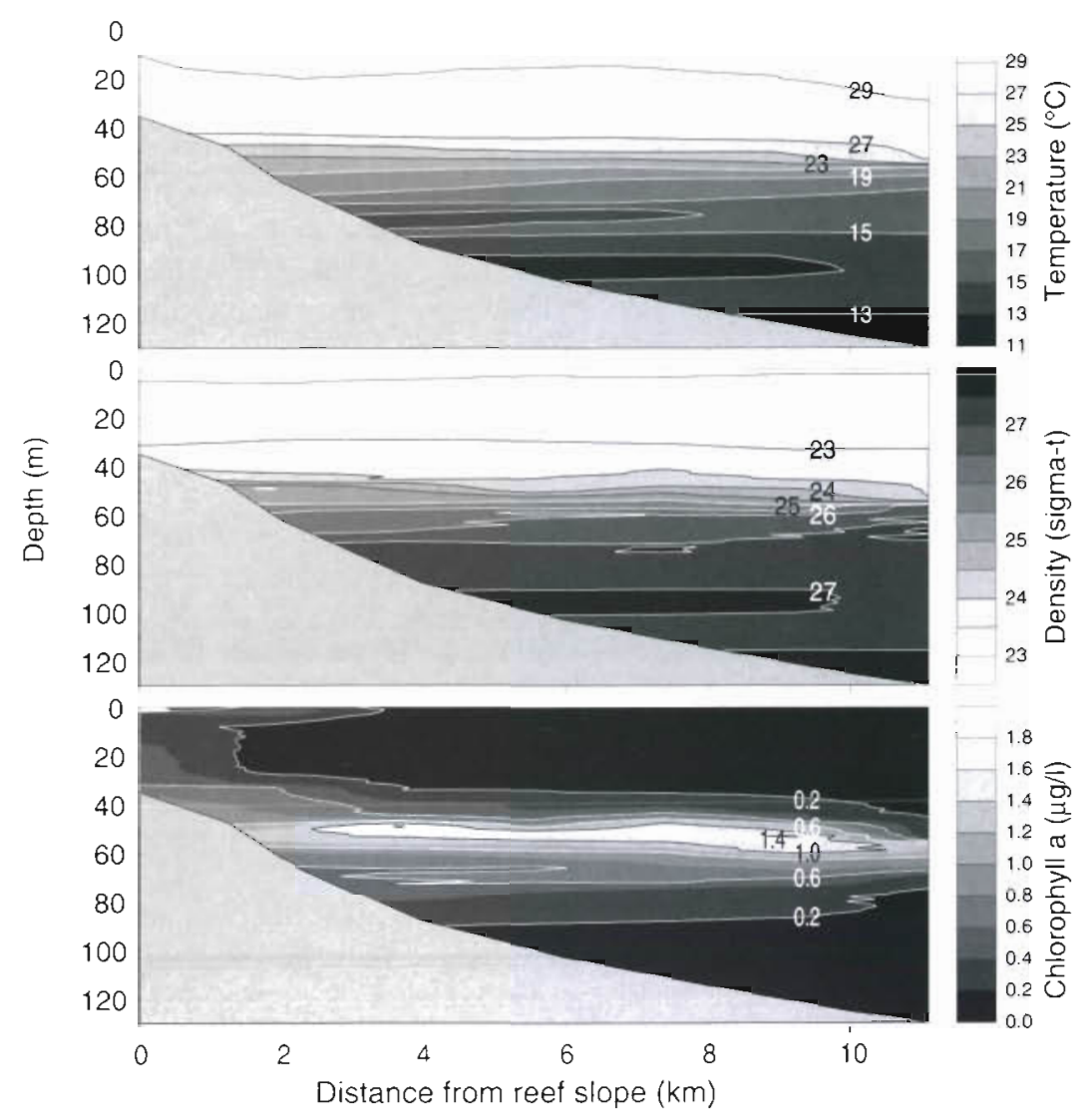

Figy. 3. Section pluts of tempelature, ciensity, anci chiorophyii a concentration lcaìibrated from in situ fluorescencel on August 11, 1995, from the front of Conch Reef seaward to $11 \mathrm{~km}$. Data contoured from a single CTD cast at each of the stations positioned every 1 nautical mile $(1.85 \mathrm{~km})$. Shaded region at lower right represents the bottom contour

Cochran's test (Winer 1962) indicated that variances among transplant racks were homogeneous after these transformations. Post hoc pairwise comparisons between depths were made using the Tukey HSD method (Sokal \& Rohlf 1995). Because weight, volume, and branch number data were not mutually independent, Bonferroni adjustments to critical p-values for significance on parallel ANCOVA tests were made using the DunnSidak method (Sokal \& Rohlf 1995).

\section{RESULTS}

In August 1995 the water column seaward of Conch Reef was stably stratified with a sharp thermocline/pycnocline at a depth of 45 to $60 \mathrm{~m}$ separating the uniformly warm $\left(28\right.$ to $\left.30^{\circ} \mathrm{C}\right)$ relatively low density $\left(\sigma_{t}\right.$ 22.0 to 22.5 ) surface layer from considerably cooler, more saline subsurface waters. Fig. 3 shows section plots of temperature, density, and chlorophyll a concentration from the reef front to $11 \mathrm{~km}$ offshore for August 11. Below the thermocline, temperature dropped gradually to a low of $12^{\circ} \mathrm{C}$ at the deepest station $(110 \mathrm{~m}$ at $11 \mathrm{~km}$ offshore). A sharply defined layer of high chlorophyll a concentrations (1.0 to $2.0 \mu \mathrm{g} \mathrm{l}^{-1}$ ) was associated with the thermocline at 50 to $60 \mathrm{~m}$. The thermocline/pycnocline was most sharply marked at the furthest offshore sampling station and spread vertically at inshore stations, likely reflecting increased mixing along the thermocline at near shore stations.

Temperatures on the reef were consistently warm in early August, and much cooler and more variable later in the month. Fig. 4 shows temperature $1 \mathrm{~m}$ above the
Fig. 4. Temperature $1 \mathrm{~m}$ above the bottom at 21 and $33 \mathrm{~m}$ depths, August 1 to September 11, 1995. Data taken at $20 \mathrm{~min}$ sample intervals. Open and closed circles indicate full and new moons respectively

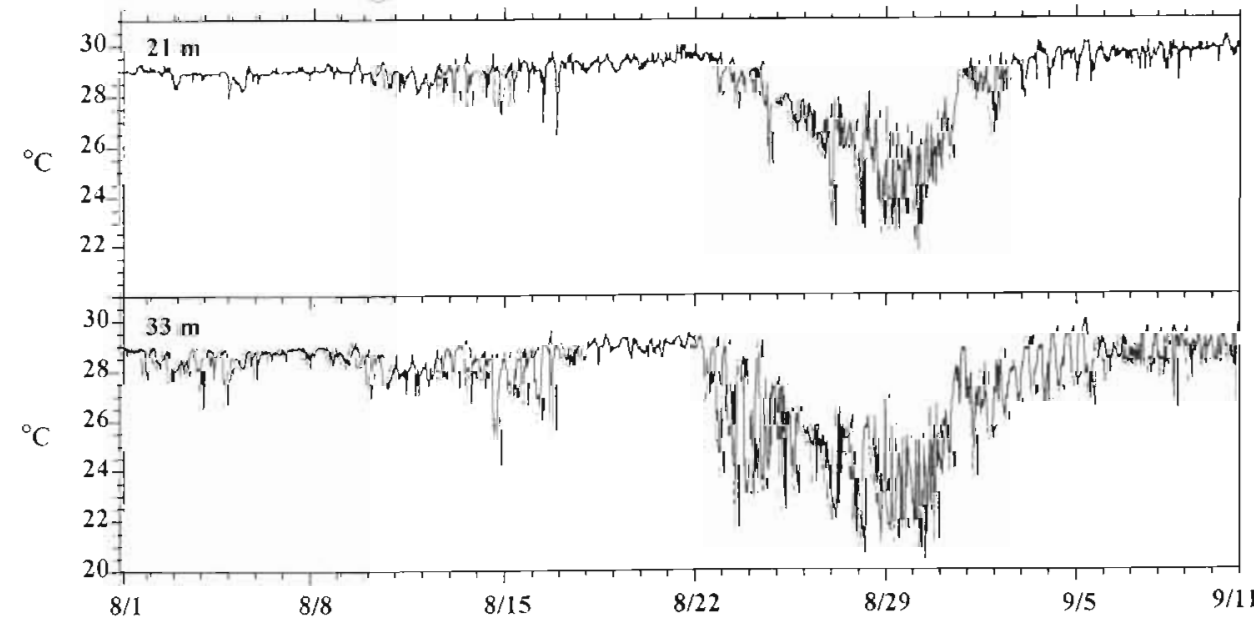




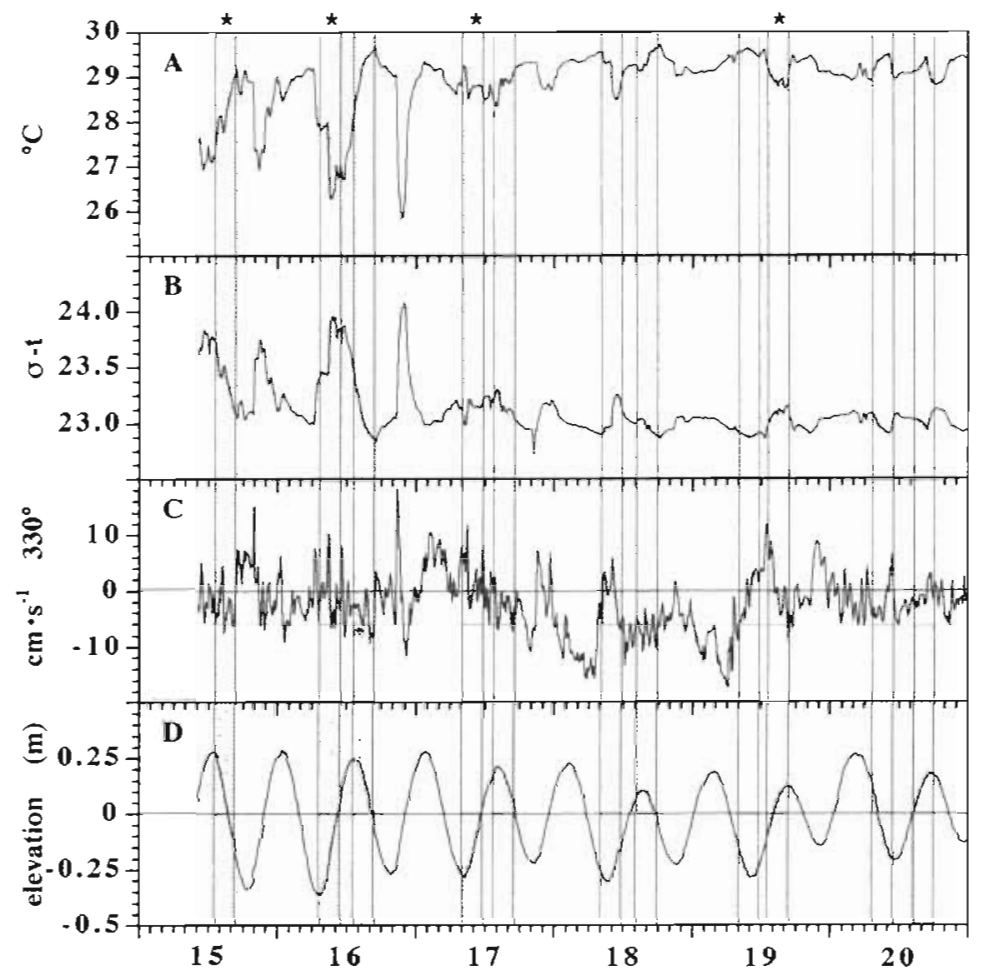

Fig. 5. (A) Temperature, (B) density, (C) $330^{\circ}$ (up-slope) component of flow, and (D) tidal elevation measured $1 \mathrm{~m}$ above the bottom at $35 \mathrm{~m}$ depth, August 15 to 20,1995. Data taken at $0.5 \mathrm{~s}$ intervals and averaged to 1 min. Gray bars show times of plankton sampling (see Fig. 6); (*) conditions associated with internal bores

reef at $33 \mathrm{~m}$ for August 1 to September 3, 1995. During the first week of August temperature at $33 \mathrm{~m}$ was relatively constant with only minor fluctuations between approximately 29 and $27^{\circ} \mathrm{C}$. Coinciding with the full moon on August 10 temperatures became more variable, with several moderately large fluctuations recorded on August 14 to 16. These days were followed by $6 \mathrm{~d}$ of relatively warm, stabile conditions until August 23 when temperature again became highly variable and considerably cooler. Coinciding with the new moon on August 24 and continuing for the next $7 \mathrm{~d}$, temperatures were highly variable with lows in the lower 20s. Within-day ranges of temperature (daily maximum minus minimum) were as large as $7.5^{\circ} \mathrm{C}$ during the last week of August 1995.

The rapid temperature changes shown in Fig. 4 were accompanied by changes in salinity, density, and flow speeds and direction. Fig. 5 shows current meter and CTD data $1 \mathrm{~m}$ above the bottom at $35 \mathrm{~m}$ for August 15 to 21,1995 . The large drops in temperature (Fig. 5A) recorded on August 15 and 16 were each accompanied by increased salinity and density (Fig. 5B). The $330^{\circ}$ component of flow speed (Fig. 5C), corresponding to flow up (positive values) and down (negative values) the reef slope, shows surges of up-slope flow associ- ated with the beginning of each cooling event. Tidal elevation data (Fig. 5D) indicate that the arrival of cool water tended to occur during flooding tides. The gray vertical bars in Figs. 5 \& 6 indicate periods of zooplankton sampling. Stars $(*)$ at the tops of the gray bars indicate times during zooplankton sampling when temperature drops and/or surges of up-slope flow suggest internal bores had arrived on the reef slope either during or within $1 \mathrm{~h}$ prior to plankton sampling.

Zooplankton concentrations tended to increase markedly with the movement of cool water onto the reef slope. Divers directly observed dense concentrations of mobile zooplankton in cool water flowing up the reef slope and reported experiencing widespread 'plankton storms' on the reef slope between 22 and $28 \mathrm{~m}$ depth during morning sampling on August 15 and 16 and afternoon sampling on August 19. Fig. 6 shows zooplankton concentrations $1 \mathrm{~m}$ above the reef for the same time period as the physical data in Fig. 5. Periods of up-slope flow of cool, high density water on August 15 and 16 coincided with high total concentrations of plankton (Fig. 6A). Plankton concentrations also increased during periods of up-slope flow on August 17 and 19 although corresponding temperature drops were small. The high zooplankton concentrations were mainly due to very large numbers (up to 3900 ind. $\mathrm{m}^{-3}$ ) of the calanoid copepods Acartia danae (Giesbrecht) (Fig. 6B) and crab zoeae (Fig. 6C). The most abundant crab zoeae were in the brachyuran family Portunidae. Other crab families represented included the anomurans Porcellanidae and Paguridae. Concentrations of fish larvae (Fig. 6D) were also relatively high in association with the arrival of cool water. These larvae were predominantly post-flexion and up to several $\mathrm{mm}$ in length. Families represented included mainly Clupeidae (herring), and also Carangidae (jacks) and Haemulidae (grunts). In contrast to the periods of up-slope flow of cool water and high plankton concentrations, periods of warmer water and days with reduced temperature variability corresponded to lower zooplankton concentrations, Very low numbers of $A$. danae were found in the warmer water, but these samples did contain several copepod species including Paracalanus spp. and cyclopoids Oithona spp. and $O$. plumifera (Baird). Fish larvae were less abundant in the warmer water samples and crab zoea were virtually absent. The concentration of fish eggs (Fig. 6E) 


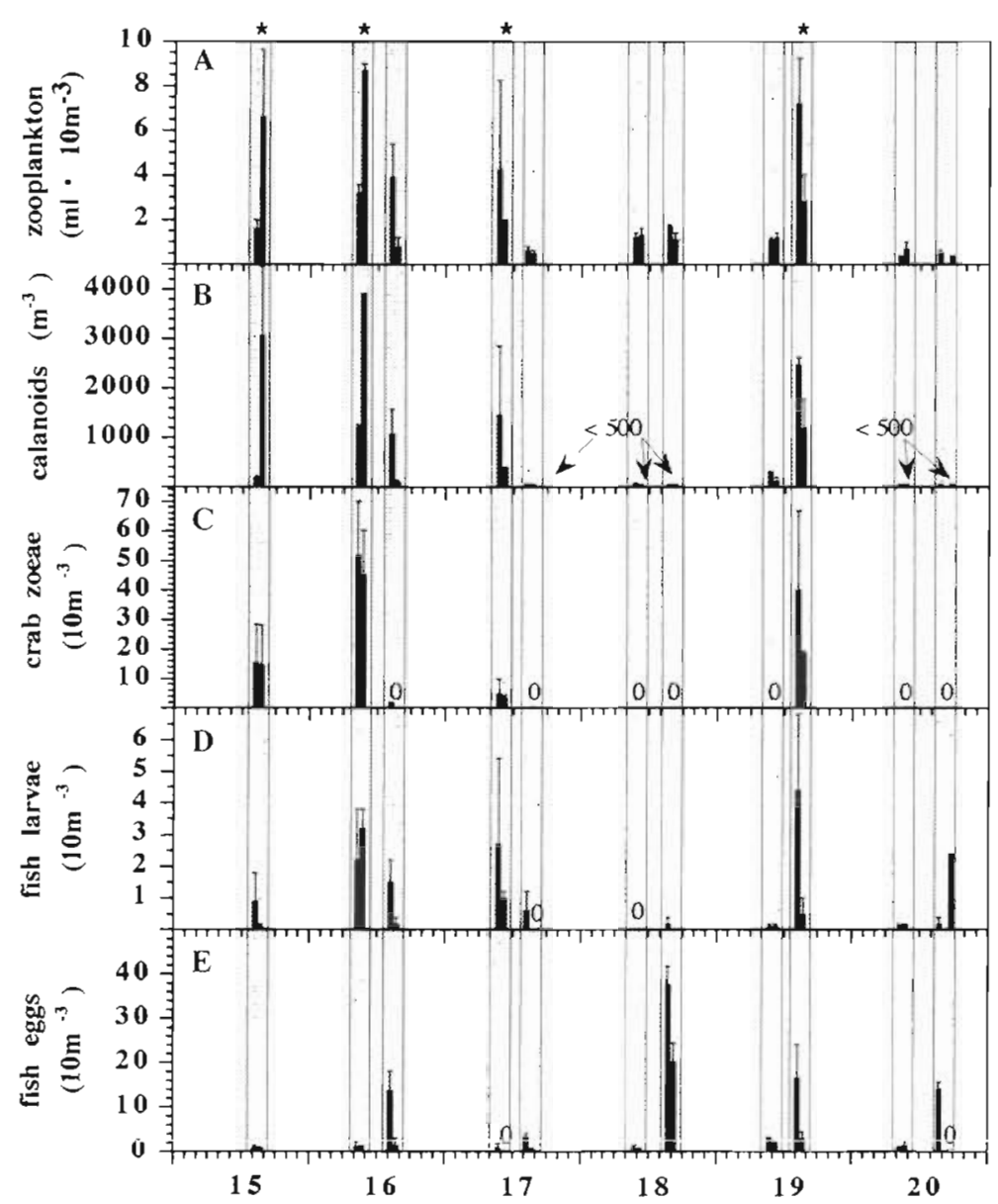

Fig. 6. (A) Total zooplankton, (B) calanoid copepods, (C) crab zoea, (D) fish larvae, and $(E)$ fish eggs collected $1 \mathrm{~m}$ above the between 22 and $28 \mathrm{~m}$ for the sample period as physical data in Fig. 5. Bars represent means and standard errors for paired plankton samples. Gray bars and * same as Fig. 5

noon of August 16. At 11:00 h temperature, salinity and chlorophyll $a$ all showed changes with depth from $29.03^{\circ} \mathrm{C}$, $36.00 \%$, and $0.355 \mu \mathrm{lg} \mathrm{l}^{-1}$ at $20 \mathrm{~m}$ to $26.46^{\circ} \mathrm{C}, 36.22 \%$, and $0.665 \mu \mathrm{g} \mathrm{l}^{-1}$ at $35 \mathrm{~m}$. By contrast, at $16: 53$ h the water column showed much more uniform warm temperatures $\left(29.6^{\circ} \mathrm{C}\right)$ and low chlorophyll a concentrations $\left(0.220 \mu \mathrm{g} \mathrm{I}^{-1}\right)$.

As fronts of cool water flowed onto the reef, thermistors at fixed positions recorded step-like changes in temperature with measurable lag times between arrival of cool water at instruments located successively up-slope. Fig. 9 shows temperature recorded synchronously at 15,20 , and $30 \mathrm{~m}$ during the arrival of cool water on the reef slope on August 14, 1995. The temperature drop was recorded first at $30 \mathrm{~m}$ and subsequently at 20 and $15 \mathrm{~m}$ with a lag of approximately $15 \mathrm{~min}$ between each location (90 to $130 \mathrm{~m}$ apart), giving an estimated up-slope travel speed of 0.10 to $0.15 \mathrm{~m} \mathrm{~s}^{-1}$ for the cool water front. The amplitude of the temperature change decreased with the movement of cool water up the reef slope.

Serpulid worms were the most common invertebrates settling on the settlement collectors. Fig. 10 shows serpulid settlement at 15,20 , and $30 \mathrm{~m}$ for the period August 3 to 23, 1995. Settlement was high at 30 and $20 \mathrm{~m}$ with means just over 42 ind. $\mathrm{m}^{-2} \mathrm{~d}^{-1}$, but was much lower at the

did not appear to track the arrival of cool water on the reef, but rather was highest during periods of warm water and off-slope flows.

The changes in plankton concentrations with changing physical conditions can be seen more clearly in Fig. 7 which expands data of Figs. $5 \& 6$ for $24 \mathrm{~h}$ on August 16, 1995. A stepped drop in temperature (Fig. 7A) was accompanied by 3 surges of up-slope flow (Fig. 7B) between 06:00 and 11:00 h, and these conditions corresponded to relatively high concentrations of calanoid copepods (large numbers of Acartia danae), crab zoeae, and fish larvae, and low concentration of fish eggs sampled at 09:30 and 10:30 h. At 15:30 and 16:10 h temperature had warmed, flow was off-slope and fewer copepods (very few $A$. danae) and fish and virtually no crab zoeae were captured. However, fish eggs were abundant in this warmer water flowing offshore. Fig. 8 shows profiles of temperature, salinity, and chlorophyll a through the water column above the reef corresponding to the morning and aftershallow station with a mean of just over $13 \mathrm{~m}^{-2} \mathrm{~d}^{-1}$ at $15 \mathrm{~m}$. Among-depth differences were highly statistically significant by the Kruskal-Wallis test (Table 1).

Table 1. Results of Kruskal-Wallis and non-parametric Tukeytype multiple comparison tests for serpulid worm settlement

\begin{tabular}{|c|c|c|c|c|}
\hline Depth $(\mathrm{m})$ & Mean & SE & $\mathrm{n}$ & Rank sum \\
\hline 15 & 13.1 & 2.8 & 10 & 72.0 \\
\hline 20 & 42.3 & 6.6 & 10 & 202.5 \\
\hline 30 & 42.7 & 9.0 & 10 & 190.5 \\
\hline \multicolumn{5}{|c|}{$H=13.51, \mathrm{df}=2, \mathrm{p}=0.001$} \\
\hline \multicolumn{2}{|l|}{ Multiple comparisons } & q & \multicolumn{2}{|r|}{ q crit. } \\
\hline 15 vs 20 & \multicolumn{2}{|r|}{$13.05^{\circ}$} & \multicolumn{2}{|r|}{3.314} \\
\hline 15 vs 30 & \multirow{2}{*}{\multicolumn{2}{|c|}{$\begin{array}{c}11.85^{\circ} \\
3.314\end{array}$}} & \multicolumn{2}{|r|}{3.314} \\
\hline 30 vs 20 & & & & \\
\hline$\cdot p<0.05$ & & & & \\
\hline
\end{tabular}




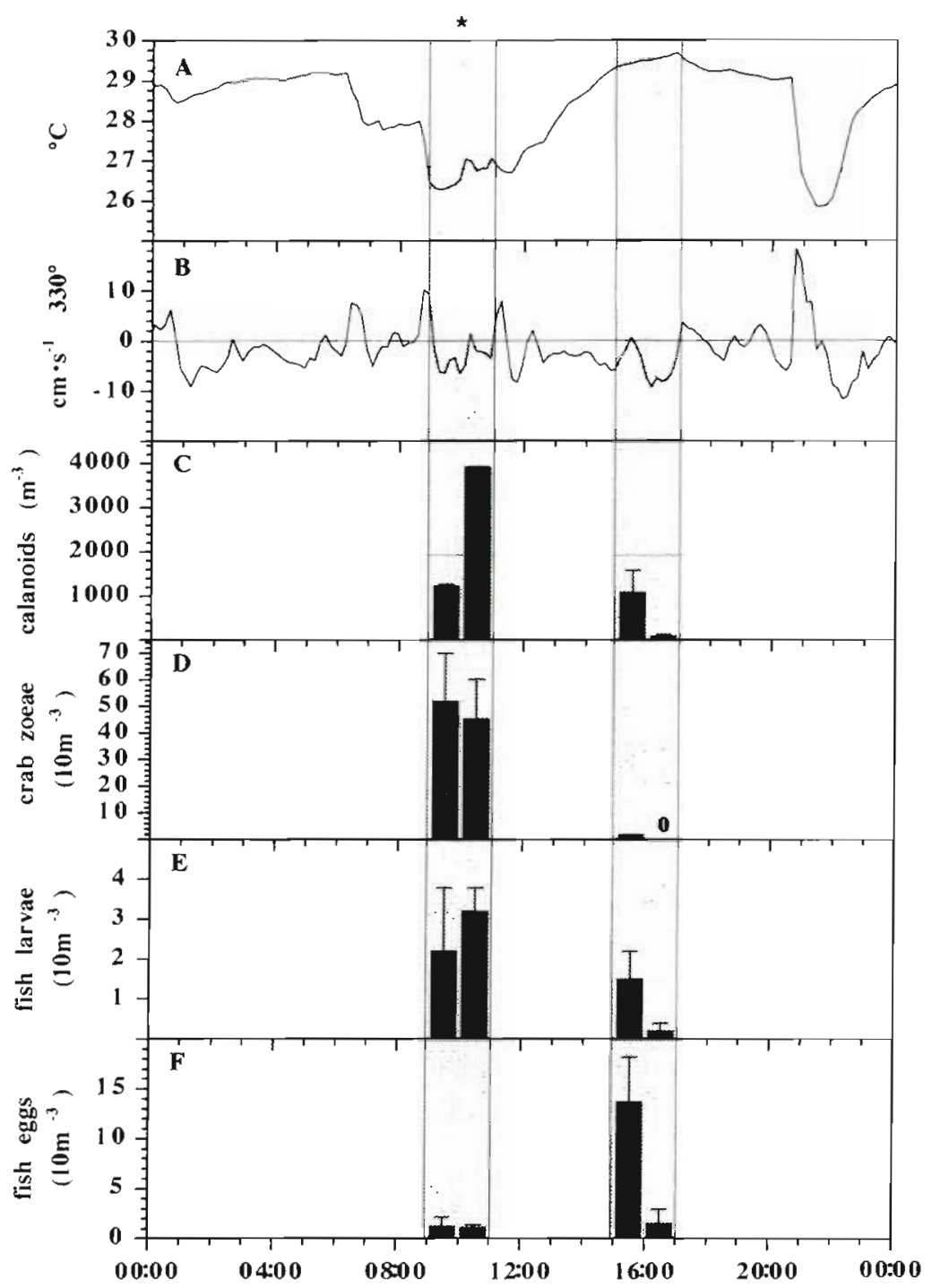

Fig. 7. (A) Temperature, (B) $330^{\circ}$ (up-slope) component of flow, (C) calanoid copepods, (D) crab zoea, (E) fish larvae, and (F) fish eggs $1 \mathrm{~m}$ above the bottom on August 16,1995. Bars represent means and standard errors for paired plankton samples. Gray bars and * as in Figs. $5 \& 6$

Between-group comparisons showed the $15 \mathrm{~m}$ treatment was highly significantly different from both other groups, and that settlement at $20 \mathrm{~m}$ did not differ significantly from that at $30 \mathrm{~m}$.

Survivorship of transplanted Madracis mirabilis fragments was high ( $87 \%$ overall) and all surviving transplants grew measurably during the 474 d growth experiment. None of the surviving corals showed scars from predation by parrotfish (Scaridae) or other corallivores. Growth was greatest at the deep site $(30 \mathrm{~m})$ with these corals becoming both larger and more branched than individuals transplanted to 20 and $15 \mathrm{~m}$. Mean growth rate and number of branches was higher at $15 \mathrm{~m}$ than at $20 \mathrm{~m}$, but these differences were not statistically significant. Fig. 11 and Table 2 show $M$. mirabilis growth rates and numbers of branches. ANCOVA showed significant effects of depth on $M$. mirabilis growth rates. Table 3 shows the ANCOVA results. Initial weights did not differ significantly between transplant racks and interaction terms between transplant rack and initial weight were all non-significant. Effects of depth and the covariate (initial weight) were highly significant, indicating that both the depth and the initial weight of transplanted individuals affected growth rates. Effects of the nested factor, rack (within depths), were non-significant. Post hoc comparisons showed significant differences between the 20 and $30 \mathrm{~m}$ treatments for weight and volume increase data and significant differences between the $30 \mathrm{~m}$ and both the 20 and $15 \mathrm{~m}$ treatments for number of new branches.

\section{DISCUSSION}

The data presented here are consistent with the general hypotheses that internal tidal bores represent a mechanism of cross-shelf transport of plankton-rich subsurface water to Florida coral reefs and that variation across depth in the impact of internal bores may influence larval supply and growth rates of benthic reef species. The sharply defined thermocline/pycnocline seaward of the Florida Keys in August 1995 represented typical summer water column stratificationconditions conducive to the propagation of internal waves and generdion of internal bores. Observations on the reef of intermittent, rapid drops in temperature accompanied by rises in salinity and density coupled to surges of flow up the reef slope $\left(330^{\circ}\right)$ all point to transient upslope movement of subthermocline water (Cairns 1967. Shanks 1995, Leichter et al. 1996). Periods of up-slope flow of cool water coincided with high concentrations of zooplankton including copepods, crab zoeae, and fish larvae, and both the growth rates of transplanted Madracis mirabilis fragments and the settlement of serpulid worms were greatest deep on the reef slope where the frequency and mean duration of cool water pulses are greatest (Leichter et al. 1996, Leichter 1997). Mixing during the generation and run-up of internal bores produces water of intermediate temperatures 


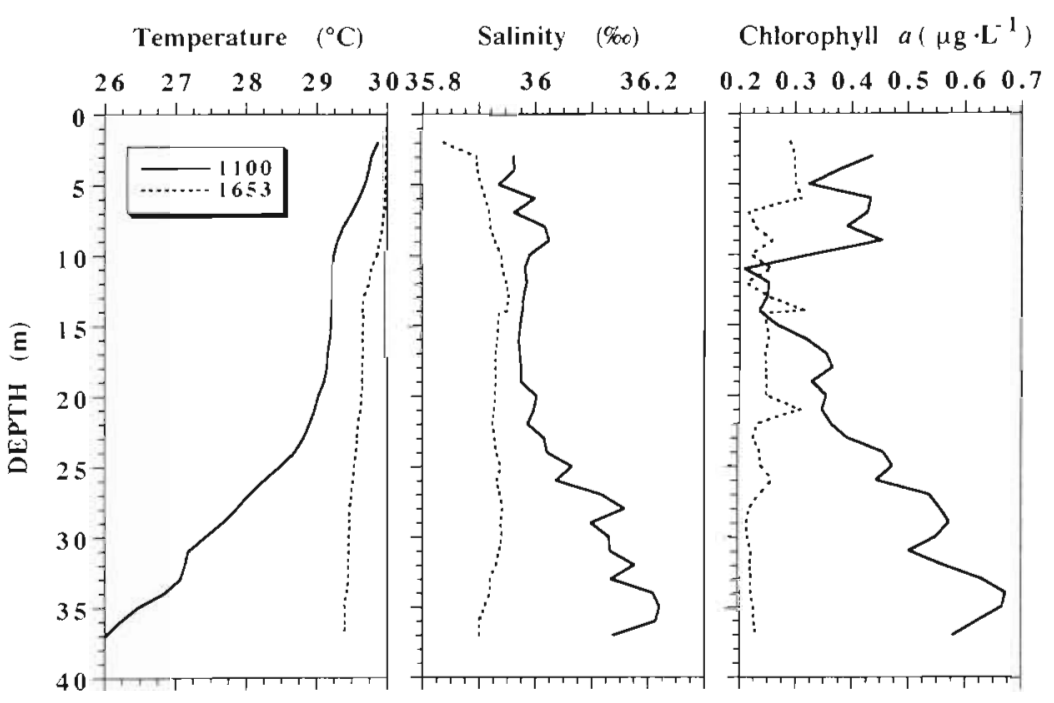

Fig. 8. Changing profiles with depth of temperature, salinity, and chlorophyll a above the reef from the morning $(11: 00 \mathrm{~h})$ to afternoon $(16.53 \mathrm{~h})$ on August 16 , 1995

and densities, so that the water surging onto the reef slope represents a mix of cool, formerly deep, water and warmer water from within and just above the thermocline. After residence times of one to several hours on the reef, this intermediate density water tends to recede in down-slope gravity currents (Leichter et al. 1996). During the residence time of internal bore water on the reef, material such as plankton and dissolved nutrients may be captured or taken up by reefdwelling suspension feeders. While water transported in internal bores cannot simply accumulate on the reef, mixing and uptake prior to the down-slope return flow may lead to net transport of waterborne material to the reef. Further, material from the reef that mixes with or is released into the intermediate-density internal bore water may be transported off the reef in down-slope

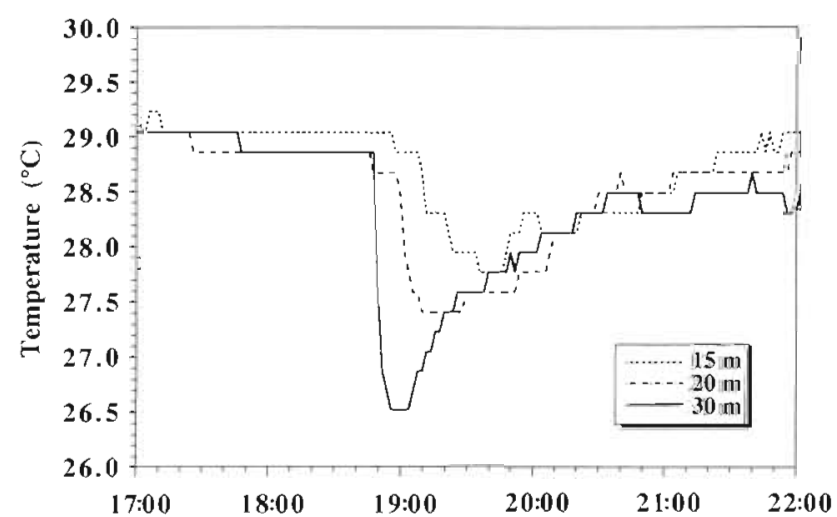

Fig. 9. Temperature measured $1 \mathrm{~m}$ above the bottom at 15,20 , and $30 \mathrm{~m}$ during the arrival of an internal bore on the reef slope on August 14, 1995 return flows toward the offshore subsurface pycnocline.

The plankton samples reveal several important patterns: First, the arrival of cool water on the reef slope is associated with large increases in phytoplankton and zooplankton concentrations and changes in plankton species abundance. Several planktonic taxa, including crab zoeae, were virtually absent in warmer water samples, yet abundant in cool water associated with internal bores. Direct visual observations by divers further emphasize both the marked increases in plankton concentrations associated with up-slope flow of cool water and the widespread nature of the phenomena on the reef slope. Second, overall plankton abundance were greatest on days with increased physical variability (temperature, salinity, currents) indicative of internal bore activity. Because internal tidal activity is linked to lunar periodicity (Fig. 4, and Leichter et al. 1996) this mechanism should produce increased plankton delivery to the reef in association with spring/neap tidal cycles. Such periodicity of transport could contribute to fortnightly cycles of settlement, patterns which have been observed in a number of geographic locations for both invertebrates (e.g. Shanks 1986, Morgan 1996) and fish (e.g. Robertson et al. 1988). Third, plankton concentrations and flow speeds tend to increase synchronously, producing high fluxes of plankton and suspended particles past the reef benthos. The frequency and duration of periods of

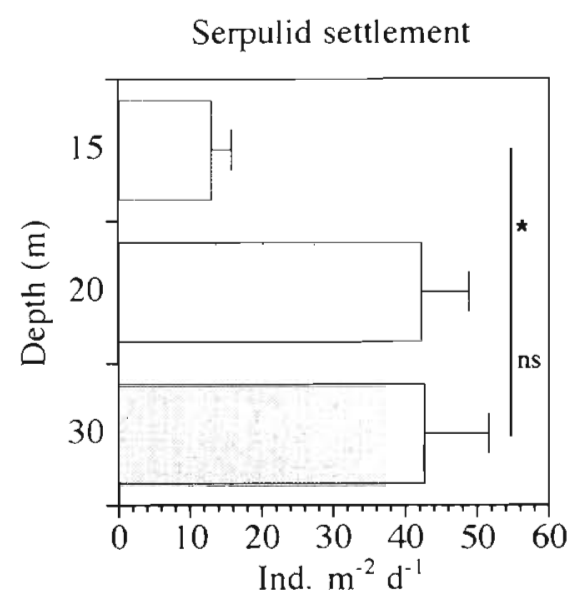

Fig. 10. Total settlement of serpulid worms at 15,20 , and $30 \mathrm{~m}$, August 3 to 23, 1995. Bars represent within-depth means and standard errors. ( $\star$ ) Significant differences at $\alpha=0.05$; ns: not significant 

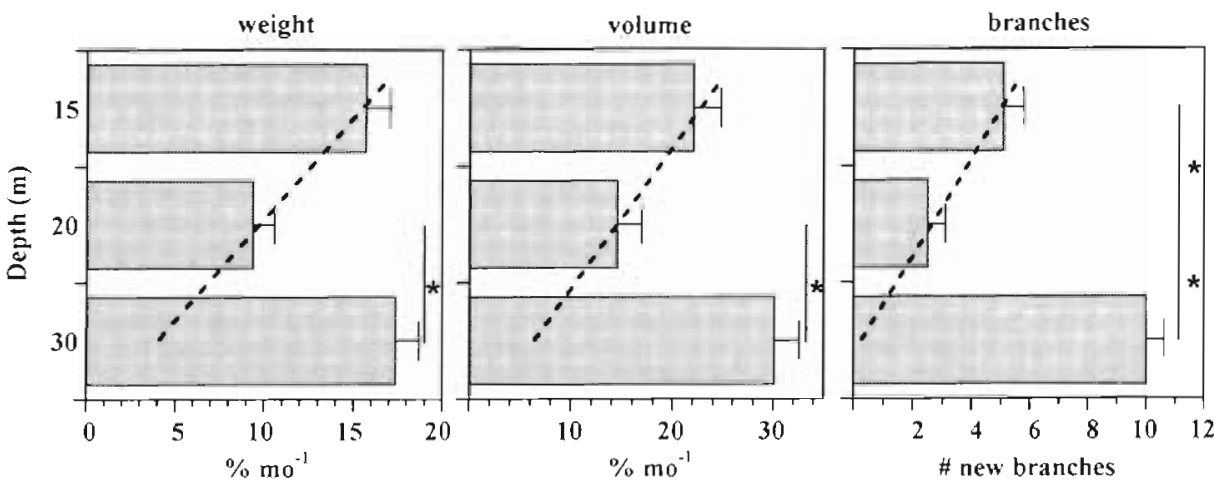

Fig. 11. Madracis mirabilis. Increases in skeletal weight, volume, and number of branches for fragments transplanted to 15 , 20 , and $30 \mathrm{~m}$. Bars represent within-depth means and standard errors. (*) Significant differences at $\alpha=0.05$ Dashed lines suggest growth that might have been expected at $30 \mathrm{~m}$ given a linear decline from 15 to 20 to $30 \mathrm{~m}$. ANCOVA indicated significant effects of depth and initial coral weight on growth high particle fluxes increase with depth on the reef slope. Fourth, down-slope flows following sets of internal bores can carry material off the reef and toward the offshore pycnocline. High concentrations of reef fish eggs could, for example, be transported offshore by this mechanism, possibly facilitating development away from shallow-water benthic predators. Plankton transport by internal bores can be viewed as a 2 -directional process in which material is moved both from the pycnocline up to the reef slope and from the reef slope out to the pycnocline and the associated subsurface chlorophyll a maximum layer.

In summer, when surface temperatures are at their seasonal high between 29 and $30^{\circ} \mathrm{C}$, the water column tends to be stably stratified essentially into 2 distinct layers separated by a strong thermocline/pycnocline. While both surface and deep waters contain very low concentrations of chlorophyll a (an indicator of phytoplankton abundance), a well-defined subsurface chlorophyll a maximum layer with concentrations as high as $2.0 \mu \mathrm{g} \mathrm{l}^{-1}$ was closely associated with the

Table 2. Madracis mirabilis transplant experiment results Group mean and standard errors (given in parentheses). Least square means (LSM) adjusted for the significant effect of initial weight are also shown for volume and weight increase

\begin{tabular}{|lccc|}
\hline & $15 \mathrm{~m}$ & $20 \mathrm{~m}$ & $30 \mathrm{~m}$ \\
\hline $\begin{array}{l}\text { Survivorship (\%) } \\
\text { Volume increase }\end{array}$ & $22.1(2.0)$ & $14.5(1.4)$ & $29.3(3.6)$ \\
$\left(\% \mathrm{mo}^{-1}\right)$ & & & \\
$\begin{array}{l}\text { LSM volume increase } \\
\left(\% \mathrm{mo}^{-1}\right)\end{array}$ & $19.6(0.04)$ & $13.0(0.05)$ & $30.7(0.05)$ \\
$\begin{array}{l}\text { Weight increase } \\
\left(\% \mathrm{mo}^{-1}\right)\end{array}$ & $15.7(1.1)$ & $9.4(0.6)$ & $17.0(1.9)$ \\
$\begin{array}{l}\text { LSM weight increase } \\
\left(\% \mathrm{mo}^{-1}\right)\end{array}$ & $14.5(0.03)$ & $8.8(0.02)$ & $16.9(0.03)$ \\
No. of new branches & $5.1(0.7)$ & $2.5(0.3)$ & $10.0(0.8)$ \\
\hline
\end{tabular}

pycnocline (Fig. 3). The formation of subsurface chlorophyll maximum layers associated with the pycnocline is typical of stratified coastal and offshore oceans, and subsurface concentrations of phytoplankton can attract aggregations of mobile zooplankton (Mann \& Lazier 1991). Thus, the pycnocline represents a zone of both likely internal wave propagation and high plankton concentrations. If a large pool of potential larvae is associated with the offshore subsurface chlorophyll maximum, cross-shelf transport by internal bores could move larvae from this pool into contact with inshore reefs and from reefs out to the larval pool. It is important to note, however, that the plankton sampling in this study was not an exhaustive comparison of internal bore and non-bore water Nor were vertical distributions of zooplankton in relation to the thermocline/pycnocline sampled. Sampling on the reef was limited to a relatively short span of days chosen for logistic reasons, and it was not possible to sample during the last week of August when cold water delivery was most intense. Had sampling coincided with the most intense internal bore activity, the observed patterns might have been even more pronounced.

Growth of Madracis mirabilis in the 15.5 mo transplant experiment represents a long-term integration of many factors that may influence growth rates, such as light availability, particle and inorganic nutrient fluxes, and water flow. Without measuring and controlling for each of these potential factors it is impossible to pinpoint conclusively the cause(s) of differences in growth between depth treatments. Enhanced growth deep on the reef slope is, however, surprising. Previous measurements at other sites have generally shown reduced coral growth rates with increasing depth (Hubbard \& Scaturo 1985, Huston 1985) for a number of species, including the reef-building coral Montastrea annularis (Dustan 1975), the brain coral Diploria labyrinthiformis, and the encrusting to mounding shallow-water species Porites asteroides (Logan \& Tomascik 1991). Reduced light availability with in- 
Table 3. Madracis mirabilis. ANCOVA for arcsine-transformed (a) volume and (b) weight increases, and for (c) log transformed number of new branches. Significance (Sig.) denoted by '; ns: not significant

\begin{tabular}{|c|c|c|c|c|c|c|c|}
\hline \multicolumn{8}{|c|}{ (a) Model: Volume increase $=$ Depth + Initial weight + Rack $($ Depth $)+$ Constant } \\
\hline Source & df & SS & MS & $F$ & $\mathrm{p}$ & p crit. & Sig. $(\alpha<0.05)$ \\
\hline Depth & 2 & 2058.82 & 1029.41 & 14.32 & 0.005 & 0.025 & $\cdot$ \\
\hline Initial weight & 1 & 2264.15 & 2264.15 & 58.35 & 0.001 & 0.017 & $\cdot$ \\
\hline Rack(Depth) & 6 & 431.46 & 71.91 & 1.85 & 0.102 & 0.025 & ns \\
\hline Errot & 67 & 2599.94 & 38.81 & & & & \\
\hline \multirow[t]{4}{*}{ Tukey post hoc: } & Comparison & $\mathrm{p}$ & p crit. & Sig. $(\alpha<0.05)$ & & & \\
\hline & 15 vs 20 & 0.167 & 0.050 & ns & & & \\
\hline & $15 \mathrm{vs} 30$ & 0.058 & 0.025 & ns & & & \\
\hline & 20 vs 30 & 0.004 & 0.025 & $\cdot$ & & & \\
\hline \multicolumn{8}{|c|}{ (b) Model: Weight increase $=$ Depth + Initial weight $+\operatorname{Rack}($ Depth $)+$ Constant } \\
\hline Source & df & SS & MS & $F$ & $\mathrm{p}$ & p crit. & $\operatorname{Sig} .(\alpha<0.05)$ \\
\hline Depth & 2 & 691.46 & 345.73 & 7.43 & 0.024 & 0.050 & $\cdot$ \\
\hline Initial weight & 1 & 224.90 & 224.91 & 10.02 & 0.002 & 0.025 & $\cdot$ \\
\hline Rack(Depth) & 6 & 279.25 & 46.54 & 2.07 & 0.068 & 0.017 & ns \\
\hline Error & 67 & 1504.17 & 22.45 & & & & \\
\hline \multirow[t]{4}{*}{ Tukey post hoc: } & Comparison & $p$ & p crit. & Sig. $(\alpha<0.05)$ & & & \\
\hline & 15 vs 20 & 0.089 & 0.025 & ns & & & \\
\hline & 15 vs 30 & 0.638 & 0.050 & ns & & & \\
\hline & 20 vs 30 & 0.023 & 0.050 & $\cdot$ & & & \\
\hline \multicolumn{8}{|c|}{ (c) Model: New branches $=$ Depth + Initial weight $+\operatorname{Rack}($ Depth $)+$ Constant } \\
\hline Source & df & SS & MS & $F$ & $\mathrm{p}$ & p crit. & Sig. $(\alpha<0.05)$ \\
\hline Depth & 2 & 16.71 & 8.36 & 29.1 .7 & 0.001 & 0.017 & $\cdot$ \\
\hline Initial weight & 1 & 1.33 & 1.33 & 6.08 & 0.016 & 0.050 & $\cdot$ \\
\hline Rack(Depth) & 6 & 1.72 & 0.28 & 1.31 & 0.264 & 0.050 & ns \\
\hline Error & 67 & 14.64 & 0.22 & & & & \\
\hline \multirow[t]{4}{*}{ Tukey post hoc: } & Comparison & $\mathrm{p}$ & p crit. & Sig. $(\alpha<0.05)$ & & & \\
\hline & 15 vs 20 & 0.043 & 0.017 & ns & & & \\
\hline & 15 vs 30 & 0.016 & 0.017 & $\cdot$ & & & \\
\hline & 20 vs 30 & 0.001 & 0.017 & $\cdot$ & & & \\
\hline
\end{tabular}

creasing depth is the most likely explanation for this general trend. The dashed lines in Fig. 11 suggest one possible expectation for growth at $30 \mathrm{~m}$ given a linear decline in growth with increasing depth. Growth at $30 \mathrm{~m}$ far exceeded this 'expectation', suggesting enhancement of growth by one or more factors.

Like many hard corals, Madracis mirabilis is both autotrophic, through capture of light energy by symbiotic zooxanthellae, and heterotrophic, through capture and ingestion of suspended particles (Sebens et al. 1996). Suspension feeding on copepods and other zooplankton can be an important source of nutrition for heterotrophic corals (Porter 1976). Studies of particle capture have shown increased capture rates with increasing flow speeds and/or particle concentrations, and it has been suggested that a branched morphol- ogy and relatively small polyp size in the congeneric species $M$. decactus aid in particle capture at higher flow speeds (Sebens \& Johnson 1991). For $M$. mirabilis, Sebens et al. (1997) have suggested that increased branching aids particle capture at high flow speeds. In the experiment presented here, corals transplanted to $30 \mathrm{~m}$ gained more skeletal weight, increased more in volume, and became more branched than those in either of the shallower treatments. The most likely explanation of these differences is overall, long-term increased food availability associated with higher particle fluxes deep on the reef. Differences between the 15 and $20 \mathrm{~m}$ treatments were not statistically significant. Slow growth rates at $20 \mathrm{~m} \mathrm{do}$, however, suggest that this depth on the reef slope may be subjected to both reduced light avail- 
ability compared with $15 \mathrm{~m}$ and reduced particle flux compared with $30 \mathrm{~m}$. Preliminary transplant experiments at Conch Reef with the vase sponge Callyspongia vaginalis have also shown increased growth with increasing depth (G. Trussel pers. comm.), suggesting that common factors may similarly affect a range of different suspension feeders on this reef slope.

The settlement experiment suggests increased larval supply with depth may be tied to increased impact of internal bores. However, the link between settlement and larval supply in this study is weak at best. A longer-term settlement experiment would clearly be necessary to show that internal bores explain between-depth differences in settlement rates, and plankton sampling would need to be focused specifically on the taxa of larvae actually settling. While settlement cannot occur without a supply of competent larvae, settlement patterns can, of course, arise by other means, such as larval preference for deeper locations or differential post-settlement mortality. The association of crab zoeae with cool water on the reef slope is highly suggestive of a role of internal bores in cross-shelf transport of these wide-dispersing larvae. Dispersal and transport of crab larvae is a widely studied topic and the potential roles of larval behavior in interacting with variable current are considerable (see Epifanio 1995, Morgan 1996). Cross-shelf transport by tidal bores appears particularly suitable for interaction with crab larval behavior because transport is limited to particular water column layers associated with the pycnocline. It has also been suggested that reproductive and larval behavior in coral reef fish may be adapted to local circulation patterns that retain larvae in the vicinity of reefs (Sale 1970, Johannes 1978, Lobel 1989). Internal tidal phenomena may contribute to widely observed patterns of lunar and semi-lunar periodicity in recruitment of invertebrates and fish (e.g. Robertson et al. 1988). Certainly, larval behaviors are sufficiently complex that it is not unreasonable to believe that particular groups of larvae could, for example, track depths associated with an offshore pycnocline and subsurface chlorophyll maximum layer and thus be ideally positioned for onshore transport in internal bores. The majority of fish larvae collected in this study were post-flexion, and thus at least potentially ready to settle when transported to the reef slope.

Internal tides, waves, and bores have received increasing research attention since the 1970s. These phenomena are widespread in both coastal and offshore oceans (Wolanski 1994, Pineda 1995) and represent an important mechanism of high frequency mixing and transport across density discontinuities (Sandstrom \& Elliot 1984, Wolanski 1994, Shanks 1995). In the rocky subtidal of the Gulf of Maine, unbroken internal waves can produce downward, ver- tical deflection of the thermocline that brings a subsurface chlorophyll maximum layer into contact with dense aggregations of benthic suspension feeders (Witman et al. 1993). While floating, neustonic material may be transported in surface slicks produced by trains of subsurface internal waves (Shanks 1983, 1986, Kingsford \& Choat 1986); horizontal transport at the pycnocline by internal waves in deep water should be slow at best. However, once internal waves break into traveling internal bores, horizontal mass transport can be considerable, especially near the bottom (Shanks 1995). For example, along the northwest coast of Australia internal bores tens of meters in height have been measured, transporting water onshore at speeds up to $0.4 \mathrm{~m} \mathrm{~s}^{-1}$ (Smyth \& Holloway 1988). While reports to date of internal waves and tidal bores on coral reefs are relatively few (Leichter et al. 1996), the conditions that give rise to these phenomena - water column density stratification, tidal forcing, and appropriate bottom topography - are prevalent in the vicinity of many coral reefs.

Because internal bores are moving, subsurface fronts of cool water, the well-studied effects of frontal systems in nearshore oceans provide a context for considering their impacts on plankton distributions and delivery. The range of mechanisms of frontal formation believed to concentrate and redistribute plankton include wind-driven Langmuir cells (Kingsford et al. 1991), island wakes and tidal jets (Wolanski \& Hamner 1988, Wolanski 1994), surface slicks over internal waves (Shanks 1983, 1986, Kingsford \& Choat 1986), estuarine plume fronts (Kingsford 1990), and boundary mixing (Shanks 1995). Internal bores along the Florida Keys reef track do not occur in isolation, but represent a high frequency phenomenon inherently linked to larger scale, lower frequency oceanographic processes which influence water column stratification and the distributions of nutrients and plankton. The run-up of internal bores is one of several potential mechanisms of cool-water upwelling, cross-shelf transport, and variability of plankton concentrations along Florida Keys reefs. Previous studies have pointed to cold core frontal eddies (Lee \& Mayer 1977, Lee et al. 1981, 1992, 1994, Lee \& Atkinson 1983) and bottom intrusions of subsurface Gulf Stream water (Atkinson 1977, Atkinson et al. 1983, Atkinson \& Blanton 1986) as sources of temperature variability and nutrient input along the shelf break of the southeast Atlantic Bight, central and northern Florida, and the lower Florida Keys. These phenomena occur on longer time scales (days to weeks) than the effects of internal bores, which are concentrated at semi-diumal frequencies. The pronounced cooling lasting several days, coupled to extreme high frequency temperature variability, recorded deep on Conch Reef on August 23 to 31, 1995 
(Fig. 4), may represent a bottom intrusion of cool water onto the shelf which would have increased water column stratification and allowed a period of heightened internal tidal activity. The impact of internal bores on the reef slope can best be thought of as a high frequency component of a suite of mechanisms that interact to produce cross-shelf transport of subsurface waters. Internal bores may be of particular importance because of their potential to cause cross-shelf transport not only on the continental shelf, but directly to the slopes of near-shore reefs.

The importance of the present study lies in the demonstration that highly dynamic, but predictable oceanographic conditions in the vicinity of a Florida coral reef produce large fluctuations in water column properties and concentrations of plankton near the benthos. Slowly developing, persistent reef communities may be shaped by highly variable physical conditions. The variation in internal bore impact on the within-reef scale of the slope at Conch Reef suggests the possibility of significant along-shore and betweenreef variation across the entire Florida Keys reef track. Preliminary results from a large scale study suggest internal bores are common throughout the Florida Keys (J. Leichter unpubl. data). The run-up of internal bores is mediated by shelf slope and topography. Traveling internal bores may be channeled by the reef spur and groove topography, and large scale reef geometry and proximity to the shelf break may influence the frequency and magnitude of internal bore effects. Internal tidal phenomena represent dynamic processes that redistribute cool water and materials in the water column from seaward distributions in relation to the thermocline to temporally and spatially dynamic distributions across reef slopes (Leichter et al. 1996). Understanding the extent to which populations of fish and invertebrates on coral reefs are sustained by local and/or long distance larval production and dispersal is important both to basic marine ecology (e.g. Sammarco \& Heron 1994, Schultz \& Cowen 1994) and to specific management and conservation decisions related to connectivity among reefs and recruitment in marine reserves (Roberts 1997). Mechanisms such as crossshelf transport in internal bores should facilitate larval transport into open populations on coral reefs along the Florida Keys reef track. Better understanding of these phenomena should enhance understanding of the complex, interacting processes that structure coastal marine populations.

Acknowledgements. This project depenced on logistical and field support from a number of energetic and generous people. We especially thank Craig Cooper, Mark Denny, William Fox, Don Girourd, Liz Kintzing, Tim Loher, Steven Miller, Loretta Roberson, Mark Samples, Judy Thompson, and the entire crew of the National Undersea Research Center and
Aquarius Habitat. Mike Connolly and the National Ocean Services (NOAA) provided instrumentation. Alicia Roth assisted with design and construction of sampling equipment. Sue Lisin and the Monterey Bay Aquarium, California, USA, provided use of microscopes, and Erika Marin-Spiotta assisted with plankton sorting. Karla Heidleberg assisted in identification of copepods. Loo Botsford and Alan Shanks provided valuable criticism of the manuscript. This research was funded by a grant from the National Oceanic and Atmospheric Administration's National Undersea Research Center at the University of North Carolina at Wilmington, USA, pursuant to NOAA award number NA36RU0060-05. Additional funding to J.J.L. was received from a National Science Foundation Pre-Doctoral Fellowship and the Lerner-Gray Fund for Marine Research.

\section{LITERATURE CITED}

Atkinson LP (1977) Modes of Gulf Stream intrusion into the South Atlantic Bight shelf waters. Geophys Res Lett 4: $583-586$

Atkinson LP, Blanton JO (1986) Processes that affect statification in shelf waters. In: Moores NK (ed) Baroclinic processes on continental shelves. American Geophysical Union, Washington, DC, p 117-130

Atkinson LP, Lee TN, Blanton JO, Chandler WS (1983) Climatology of the southeastern United States continental shelf waters. J Geophys Res 88(C8):4705-4718

Bertness MD, Gaines SD, Wahle RA (1996) Wind-driven settlement patterns in the acorn barnacle Semibalanus balanoides. Mar Ecol Prog Ser 137:103-110

Botsford LW; Moloney CL, Hastings A, Largier JL, Powell TM, Higgins K, Quinn JF (1994) The influence of spatially and temporally varying oceanographic conditions on meroplanktonic metapopulations. Deep Sea Res II 41: $107-145$

Cairns JL (1967) Asymmetry of internal tidal waves in shallow coastal waters. J Geophys Res 72:3563

Cooper LHN (1947) Internal waves and upwelling of oceanic water from mid-depths onto a continental shelf. Nature 159:579-580

Cowen RK, Castro LR (1994) Relation of coral reef fish larval distributions to island scale circulation around Barbados, West Indies. Bull Mar Sci 54:228-244

Dustan P (1975) Growth and form in the reef-building coral Montastrea annularis. Mar Biol 33:101-107

Epifanio CE (1995) Transport of blue crab (Callinectes sapidus) larvae in the waters of Mid-Atlantic states. Bull Mar Sci 57:713-725

Farrell TM, Bracher D, Roughgarden J (1991) Cross-shelf transport causes recruitment to intertidal populations in central California. Limnol Oceanogr 36:279-288

Gaines SD, Bertness MD (1992) Dispersal of juveniles and variable recruitment in sessile marine species. Nature 360:579-580

Gaines SD, Roughgarden J (1985) Larval settlement rate: a leading determinant of structure in an ecological community of the marine intertidal zone. Proc Natl Acad Sci USA $82: 3707-3711$

Hubbard DK, Scaturo D (1985) Growth rates of seven species of scleractinian corals from Cane Bay and Salt River, St Croix, USVI. Bull Mar Sci 36:325-338

Huston MA (1985) Variation in coral growth rates with depth at Discovery Bay, Jamaica. Coral Reefs 4:19-25

Johannes RE (1978) Reproductive strategies of coastal marine fishes in the tropics. Environ Biol Fishes 3:65-84

Kingsford MJ (1990) Linear oceanographic features: a focus 
for research on recruitment processes. Aust J Ecol 15: $391-401$

Kingsford MJ, Choat JH (1986) Influence of surface slicks on the distribution and onshore movements of small fish. Mar Biol 91:161-171

Kingsford M.J, Wolanski E, Choat JH (1991) Influence of tidally induced fronts and Langmuir circulations on distribution and movements of presettlement fishes around a coral reef. Mar Biol 109:167-180

Lee TN, Atkinson LP (1983) Low-frequency current and temperature variability from Gulf Stream frontal eddies and atmospheric forcing along the southeast U.S. Outer Continental Shelf. J Geophys Res 88(C8):4541-4568

Lee TN, Atkinson LP, Legekis R (1981) Observations of a Gulf Stream frontal eddy on the Georgia continental shelf, April 1977. Deep Sea Res 28A:347-378

Lee TN, Clarke ME, Williams E, Szmant AF, Berger T (1994) Evolution of the Tortugas gyre and its influence on recruitment in the Florida Keys. Bull Mar Sci 54:621-646

Lee TN, Mayer DA (1977) Low frequency current variability and spin-off eddies along the shelf of Southeast Florida. J Mar Res 35:193-220

Lee TN, Rooth C, Williams E, McGowan M, Szmant AF, Clarke ME (1992) Influence of Florida Current, gyres and wind-driven circulation on transport of larvae and recruitment in the Florida Keys coral reefs. Cont Shelf Res 12:971-1002

Leichter JJ (1997) Coastal ocean physical forcing: influences of internal tidal phenomena on Florida coral reefs. PhD thesis, Stanford University, Stanford, CA

Leichter. JJ, Wing SR, Miller SL, Denny MW (1996) Pulsed delivery of subthermocline water to Conch Reef (Florida Keys) by internal tidal bores. Limnol Oceanogr 41: 1490-1501

Lobel PS (1989) Ocean current variability and the spawning season of Hawaijan reef fishes. Environ Biol Fishes 24: $161-1416$

Logan A, Tomascik T (1991) Extension growth rates in two coral species from high-latitude reefs of Bermuda. Coral Reefs 10:155-1.60

Mann KH, Lazier JRN (1991) Dynamics of marine ecosystems. Blackwell, Boston

Morgan SG (1996) Plasticity in reproductive timing by crabs in adjacent tidal regimes. Mar Ecol Prog Ser 139:105-118

Owre HB, Foyo M (1967) Copepods of the Florida Current with illustrated keys to genera and species. Institute of Marine Science, University of Miami

Pineda J (1991) Predictable upwelling and the shoreward transport of plankton larvae by internal tidal bores. Science 253:548-551

Pineda J (1994) Internal tidal bores in the nearshore: warmwater fronts, seaward gravity currents and the onshore transport of neustonic larvae. J Mar Res 52:427-458

Pineda J (1995) An internal tidal bore regime at nearshore stations along western USA. predictable upwelling with the lunar cycle. Cont Shelf Res 15:1023-1041

Porter JW (1976) Autotrophy, heterotrophy and resource partitioning in Caribbean reef building corals. Am Nat 110 $731-742$

Possingham HP, Roughgarden J (1990) Spatial population dynamics of a marine organism with a complex life cycle Ecology 71:973-985

Roberts CM (1997) Connectivity and management of Caribbean coral reefs. Science 278:1454-1457

Robertson DR, Green DG, Victor BC (1988) Temporal coupling of production and recruitment of larvae of a Caribbean reef fish. Ecology 69:370-381

Roughgarden J, Gaines SD, Pacala SW (1.987) Supply side ecology: the role of physical transport processes. In: Gee JHR, Giller PS (eds) Organization of communities: past and present. Blackwell, Boston, p 491-518

Sale PF (1970) Distribution of larval acanthuridae of Hawaii. Copeia 1970:765-766

Sammarco PW, Heron ML (eds) (1994) The bio-physics of marine larval dispersal. American Geophysical Union, Washington, DC

Sandstrom H, Elliott JA (1984) Internal tide and solitons on the Scotian shelf: a nutrient pump at work. J Geophys Res 89:6415-6426

Schultz ET, Cowen RK (1994) Recruitment of coral-reef fishes to Bermuda: local retention of long-distance transport? Mar Ecol Prog Ser 109:15-28

Sebens KP, Johnson AS (1991) Effects of water movement on prey capture and distribution of reef corals. Hydrobiologia 226:91-101

Sebens KP, Vandersall KS, Savina LA, Graham KR (1996) Zooplankton capture by two scleractinian corals, Madracis mirabilis and Montastrea cavernosa, in a field enclosure. Mar Biol 127:303-317

Sebens KP. Witting J, Helmuth B (1997) Effects of water flow and branch spacing on particle capture by the reef coral Madracis mirabilis (Duchassaing and Michelotti). J Exp Mar Biol Ecol 211:1-28

Shanks AL (1983) Surface slicks associated with tidally forced internal waves may transport pelagic larvae of benthic invertebrates and fishes shoreward. Mar Ecol Prog Ser 13: $311-315$

Shanks AL (1986) Tidal periodicity in the daily settlement of intertidal barnacle larvae and an hypothesized mechanism for the cross-shelf transport of cyprids. Biol Bull (Woods Hole) 170:429-440

Shanks AL (1995) Mechanisms of cross-shelf dispersal of larval invertebrates and fish. In: McEdward L (ed) Ecology of marine invertebrate larvae. CRC Press, Boca Raton, FL, p 323-367

Shinn EA, Lidz BH, Kindinger JL, Hudson JH, Halley RB (1989) Reefs of Florida and the Dry Tortugas: a guide to the modern carbonate environments of the Florida Keys and the Dry Tortugas. US Geological Survey, St Petersburg, FL

Smyth NF, Holloway PE (1988) Hydraulic jump and undular bore formation on a shelf break. J Phys Oceanogr 18: $947-962$

Sokal RR, Rohlf FJ (1995) Biometry, 3rd edn. WH Freeman and Co, New York

Sulkin SD (1984) Behavioral basis of depth regulation in the larvae of brachyuran crabs. Mar Ecol Prog Ser 15:181-205

Thornson G (1950) Reproduction and larval ecology of marine bottom invertebrates. Biol Rev Cambr Philos Soc 25:1-45

Underwood A.J, Chapman MG (1996) Scales of spatial patterns of distribution of intertidal invertebrates. Oecologia $107: 212-224$

Winer BJ (1962) Statistical principles in experimental design. McGraw Hill, New York

Wing SR, Botsford LW, Largier JL, Morgan LE (1995a) Spatial structure of relaxation events and crab settlement in the northern California upwelling system. Mar Ecol Prog Ser 128:199-211

Wing SR, Largier JL, Botsford LW, Quinn JF (1995b) Settlement and transport of benthic invertebrates in an intermittent upwelling region. Limnol Oceanogr 40:316-329

Witman JD, Leichter JJ, Genovese SJ, Brooks DA (1993) Pulsed phytoplankton supply to the rocky subtidal zone: influence of internal waves. Proc Natl Acad Sci USA 90: $1686-1690$ 
Wolanski E (1994) Physical oceanographic processes of the Great Barrier Reef. CRC Press. Boca Raton, FL

Wolanski E, Hamner WH (1988) Topographically controlled fronts in the ocean and their biological influence. Science $241: 177-181$

Wolanski E, Pickard GL (1983) Upwelling by internal tides

Editorial responsibility: Charles Peterson (Contributing Editor), Morehead City, North Carolina, USA and Kelvin waves at the continental shelf break on the Great Barrier Reef. Aust J Mar Res 34:65-80

Young CM (1990) Larval ecology of marine invertebrates: a sesquicentennial history. Ophelia 32:1-48

Zar JH (1984) Biostatistical analysis. Prentice Hall, Englewood Cliffs, NJ

Submitted: August 9, 1997; Accepted: February 11, 1998 Proofs received from author(s): April 28, 1998 